\title{
Pengaruh Variasi Konsentrasi Natrium Klorida Dalam Formulasi Sediaan Facial Wash Kombinasi Ekstrak Spirulina (Spirulina platensis ) Dan Minyak Nyamplung (Chalophyllum inophyllum)
}

\author{
Artanti AN ${ }^{1 *}$, Prabawati $\mathbf{N}^{1}$, Prihapsara $\mathbf{F}^{\mathbf{1}}$, Rakhmawati $\mathbf{R}^{\mathbf{1}}$ \\ ${ }^{1}$ Program Studi D3 Farmasi, Sekolah Vokasi Universitas Sebelas Maret \\ Program Studi Farmasi, Fakultas MIPA Universitas Sebelas Maret \\ *email korespondensi : anif.apt@staff.uns.ac.id
}

Riwayat artikel: Dikirim: 11/11/2020; Diterima: 18/11/2020, Diterbitkan: 1/07/2021

\begin{abstract}
ABSTRACK
Spirulina platensis (nyamplung) is known to contain phycocyanin which has the potential as an antioxidant and natural dye. Nyamplung oil is a cosmetic raw material that has not been widely used. Nyamplung oil has antibacterial and antioxidant properties, so it has the potential to make cosmetic preparations, one of which is a facial wash. This study was conducted to determine the effect of variations in $\mathrm{NaCl}$ concentration on the physical properties of facial wash preparations of spirulina extract and nyamplung oil.The research was conducted using a laboratory experimental method with the stages of making soap base, making facial wash with three variations of $1 \% \mathrm{NaCl}$ concentration; $2 \%$; and $3 \%$, as well as physical and chemical properties tests in the form of organoleptic tests, viscosity tests, foam stability tests, and $\mathrm{pH}$ tests. Then the results of organoleptic tests, $\mathrm{pH}$ tests, viscosity tests, foam stability tests were compared with the Indonesian National Standard and other literature. The results showed that variations in $\mathrm{NaCl}$ concentration had a significant effect on the physical properties of the preparation, namely, the higher the $\mathrm{NaCl}$ concentration, the higher the viscosity, but the lower the foam stability. Formula 3 with $3 \% \mathrm{NaCl}$ concentration is the most stable formula for a facial wash with spirulina extract and nyamplung oil.
\end{abstract}

Keyword : Facial wash, spirulina, nyamplung, saponification

\begin{abstract}
ABSTRAK
Spirulina platensis diketahui mengandung fikosianin yang berpotensi sebagai antioksidan dan pewarna alami. Minyak nyamplung merupakan bahan baku kosmetik yang belum banyak digunakan. Minyak nyamplung berkhasiat sebagai antibakteri dan antioksidan, sehingga berpotensi untuk dibuat sediaan kosmetik salah satunya facial wash. Penelitian ini dilakukan untuk mengetahui pengaruh variasi konsentrasi $\mathrm{NaCl}$ terhadap sifat fisik sediaan facial wash ekstrak spirulina dan minyak nyamplung. Penelitian dilakukan dengan metode eksperimental laboratorium dengan tahapan pembuatan basis sabun, pembuatan facial wash dengan tiga variasi konsentrasi $\mathrm{NaCl} 1 \%$; 2\%; dan 3\%, serta uji sifat fisik dan kimia berupa uji organoleptik, uji viskositas, uji stabilitas busa, dan uji $\mathrm{pH}$. Kemudian hasil pengujian organoleptik, uji $\mathrm{pH}$, uji viskositas, uji stabilitas busa dibandingkan dengan Standar Nasional Indonesia dan literatur lainnya. Hasil penelitian menunjukkan bahwa variasi konsentrasi $\mathrm{NaCl}$ memberikan pengaruh signifikan terhadap sifat fisik sediaan, yaitu semakin tinggi konsentrasi $\mathrm{NaCl}$ maka viskositas semakin meningkat namun stabilitas busa semakin menurun. Formula 3 dengan konsentrasi $\mathrm{NaCl} 3 \%$ merupakan formula facial wash ekstrak spirulina dan minyak nyamplung yang paling stabil.
\end{abstract}

Kata Kunci : Facial wash, spirulina, nyamplung, saponifikasi 
DOI : https://doi.org/10.24843/JFU.2021.v10.i01.p11

\section{PENDAHULUAN}

Kandungan fikosianin dalam Spirulina platensis memiliki aktivitas antioksidan dan antiradikal yang signifikan serta dapat mengikat logam berat (Bashandy dkk, 2016). Pada penelitian Agustini, (2012), pigmen fikobiliprotein pada Spirulina platensis terdiri dari pigmen fikosianin, dan allofikosianin, pigmen fikobiliprotein memiliki IC $_{50}$ sebesar 96,57 $\mu \mathrm{g} / \mathrm{mL}$, pigmen fikobiliprotein dapat dinyatakan aktif sebagai antioksidan karena mempunyai nilai $\mathrm{IC}_{50}<200 \mu \mathrm{g} / \mathrm{mL}$. Hal ini sesuai dengan penelitian Hirata dkk, (2000), yang menyatkana bahwa pigmen fikobiliprotein dari mikroalga Spirulina platensis mempunyai aktivitas antioksidan yang dapat meredam radikal AAPH (2,2'azobis

(2-amidinopropane) dihydroxychloride). Spirulina memiliki kandungan biopigmen fikosianin lebih tinggi dari tanaman lain (Liu dkk, 2000). Kandungan pigmen fikosianin juga mempunyai potensi sebagai pewarna alami dalam facial wash ini.

Minyak nyamplung merupakan salah satu bahan aktif yang baik untuk kosmetik. Minyak nyamplung mengandung senyawa flavonoid dan saponin yang memiliki aktivitas antibakteri terhadap Staphylococcus aureus (Hasibuan dkk, 2013). Staphylococcus aureus merupakan salah satu bakteri penyebab jerawat (Apriani dkk, 2014). Kandungan fenolik dalam minyak nyamplung berpotensi sebagai antioksidan. Hal ini dibuktikan dengan potensi penghambatan radikal bebas yang sangat signifikan ditunjukkan oleh semua sampel uji Callophyllum inophyllum dengan nilai $\mathrm{IC}_{50}$ mulai dari 1,0 $\mu \mathrm{g} / \mathrm{mL}$ hingga $13,0 \mu \mathrm{g} / \mathrm{mL}$. Aktivitas penghambatan radikal bebas tertinggi terdapat pada ekstrak metanol dengan nilai $\mathrm{IC}_{50}=1,0 \pm 0,22 \mu \mathrm{g} / \mathrm{mL}$ ) yang dapat dikorelasikan dengan kandungan

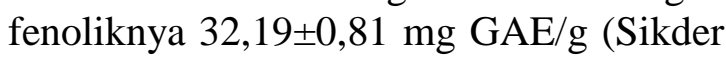
$\mathrm{dkk}, 2013$ ).

Minyak nyamplung mudah menyerap ke dalam kulit, membuat kulit halus dan lembut (Australian Botanical Product, 2011). Minyak nyamplung melindungi kulit dan meregenerasi sel (Dweck \& Meadows, 2002), melembabkan kulit, mengurangi iritasi akibat terbakar sinar matahari dan peradangan (Athar dan Nasir, 2005), serta sebagai anti-aging dan ultraviolet protector (Hieu dan Thuy, 2016). Minyak Calophyllum inophyllum baik dalam penyerapan UV-B dan UV-A (Boucher, 2000). Hasil uji nilai SPF minyak nyamplung secara in vitro dengan metode spektrofotometri yaitu pada konsentrasi $0,2 \mathrm{mg} / \mathrm{mL}$ menghasilkan nilai SPF 10,$34 ;$ konsentrasi $0,25 \mathrm{mg} / \mathrm{mL}$ menghasilkan nilai SPF 17,28 dan konsentrasi $0,3 \mathrm{mg} / \mathrm{mL}$ menghasilkan nilai SPF26,07 (Rejeki, 2015). Berdasarkan Food and Drug Administrastion (FDA) nilai SPF pada konsentrasi $0,2 \mathrm{mg} / \mathrm{mL}$ termasuk rendah karena memiliki nilai SPF antara 2-12 sedangkan pada konsentrasi $0,25 \mathrm{mg} / \mathrm{mL}$ dan $0,30 \mathrm{mg} / \mathrm{mL}$ termasuk kategori sedang karena memiliki nilai antara 12-30.

Pengental memiliki peran penting dalam memperbaiki mutu sediaan sabun wajah. Bahan pengental yang digunakan adalah natrium klorida $(\mathrm{NaCl}) . \quad \mathrm{NaCl}$ merupakan garam inorganik yang digunakan sebagai pengental dalam sebagian besar sediaan kosmetik yang mengandung detergent. Penambahan elektrolit atau garam umumnya berkisar antara $0,1 \%-3 \% b / v$, disesuaikan dengan komposisi bahan serta konsentrasi dan viskositas yang diinginkan (Oudt, 2004). Berdasarkan kemampuan $\mathrm{NaCl}$ tersebut, serta belum dilakukan pembuatan sabun wajah dengan bahan ekstrak spirulina dan minyak nyamplung. Maka peneliti ingin memformulasikan sabun cair pembersih wajah dengan variasi konsentrasi $\mathrm{NaCl}($ $1 \%, 2 \%$ dan 3\%), sehingga diperoleh facial wash yang memiliki karakteristik sesuai dengan Standar Nasional Indonesia 064085-1996 tentang sabun cair dan diperoleh nilai kesukaan yang baik 
DOI : https://doi.org/10.24843/JFU.2021.v10.i01.p11

\section{BAHAN DAN METODE}

\subsection{Bahan}

Ekstrak spirulina yang diperoleh dari PT. Neo Algae Indonesia Makmur Sukoharjo; Minyak nyamplung dari CV. Andromeda; aqua demineralisata dari ROFA Laboratorium Centre; pewarna briliant blue C.I. 42090, fragrance vanila, dan aquadest dari CV. Agung Jaya; $\mathrm{KOH}$, minyak kelapa, minyak zaitun, $\mathrm{NaCl}$ dan natrium benzoat dari Laboratorium Farmasi UNS.

\subsection{Metode}

\subsubsection{Formula basis sabun}

Pembuatan basis sabun ini digunakan perbandingan minyak, $\mathrm{KOH}$, dan aquadest sebesar (100:19:38). Dalam pembuatan basis sabun untuk sediaan facial wash ini digunakan minyak nabati dari kombinasi minyak zaitun dan minyak kelapa dengan perbandingan 80:20.

2.2.2. Pembuatan basis sabun

Pembuatan basis sabun dengan proses saponifikasi dengan cara melarutkan 19 gram $\mathrm{KOH}$ ke dalam 38 gram aquadest, ditunggu hingga suhunya turun mencapai $32-35^{\circ} \mathrm{C}$. Kemudian ditimbang 20 gram minyak kelapa dan 80 gram minyak zaitun, setelah itu keduanya dicampur menjadi satu. Kemudian pada campuran tersebut ditambahkan larutan $\mathrm{KOH}$ sedikit demi sedikit sambil terus diaduk menggunakan hand-blender dengan kecepatan 20.000rpm hingga terbentuk trace, yaitu adonan yang mengental dan kaku. Setelah terbentuk trace dilanjutkan dengan proses pemanasan pada suhu $70^{\circ} \mathrm{C}$ menggunakan alat slow-cooker selama \pm 3 jam. Selanjutnya dilakukan proses pematangan atau pemeraman sabun (curing), dengan cara menyimpan sabun pada suhu ruang selama minimal dua sampai tiga minggu sebelum masuk ke tahap pembuatan sediaan facial wash.

2.2.3. Formulasi facial wash ekstrak spirulina dan minyak nyamplung

Sediaan yang dibuat dalam penelitian ini adalah facial wash yang berwujud cair. Pembuatan facial wash pada penelitian ini dilakukan dengan memvariasikan konsentrasi natrium klorida $(\mathrm{NaCl})$. Variasi konsentrasi $\mathrm{NaCl}$ bertujuan untuk mengetahui pengaruh pemberian $\mathrm{NaCl}$ yang dapat memberikan karakteristik facial wash yang memenuhi persyaratan. Natrium klorida $(\mathrm{NaCl})$ adalah garam inorganik yang digunakan sebagai pengental dalam sebagian besar sediaan kosmetik yang mengandung detergent. Penambahan elektrolit pada umumnya berkisar antara $0,1 \%-3 \% \quad b / v$, disesuaikan dengan komposisi bahan serta konsentrasi dan viskositas yang diinginkan (Oudt, 2004). Dalam penelitian ini digunakan tiga konsentrasi $\mathrm{NaCl}$ yaitu $\mathrm{NaCl} 1 \%$ untuk Formula 1, $\mathrm{NaCl} 2 \%$ untuk formula 2, dan $\mathrm{NaCl} 3 \%$ untuk formula $3 . \mathrm{NaCl}$ ditambahkan dalam bentuk larutan agar homogen dalam sediaan.

\section{HASIL}

Tujuan dilakukannya uji organoleptik adalah untuk mengetahui bentuk sediaan secara visual melalui panca indra manusia. Hasil pengamatan organoleptik tersaji pada Tabel 1.

Tabel 1. Hasil pengujian organoleptik

\begin{tabular}{ccc}
\hline \multirow{2}{*}{ Formula } & $\begin{array}{c}\text { Parameter } \\
\text { organoleptik }\end{array}$ & Hasil pengamatan \\
\hline \multirow{2}{*}{ F1 } & Warna & Hijau \\
\cline { 2 - 3 } & Bau & Vanila \\
\cline { 2 - 3 } F2 & Bentuk & Cair \\
\cline { 2 - 3 } & Warna & $\begin{array}{c}\text { Hijau agak } \\
\text { keputihan }\end{array}$ \\
\cline { 2 - 3 } & Bau & Vanila \\
\hline \multirow{2}{*}{ F3 } & Bentuk & Cair sedikit kental \\
\cline { 2 - 3 } & Warna & Hijau keputihan \\
\cline { 2 - 3 } & Bau & Vanila \\
\hline
\end{tabular}

Berdasarkan hasil pengujian $\mathrm{pH}$ diperoleh nilai $\mathrm{pH}$ yang relatif basa yaitu 9,7. Pada ketiga formula mengalami peningkatan viskositas seiring dengan meningkatnya konsentrasi $\mathrm{NaCl}$. Hasil uji viskositas dapat dilihat pada Tabel 2. 
DOI : https://doi.org/10.24843/JFU.2021.v10.i01.p11

pISSN: 2301-7716; eISSN: 2622-4607

Jurnal Farmasi Udayana, Vol 10, No 1, Tahun 2021, 93 - 99

\begin{tabular}{cc}
\hline \multicolumn{2}{c}{ Tabel 2. Hasil uji viskositas } \\
\hline Formula & Viskositas \\
\hline F1 & $40 \pm 0,10 \mathrm{cPs}$ \\
\hline F2 & $66 \pm 0,15 \mathrm{cPs}$ \\
\hline F3 & $83 \pm 0,20 \mathrm{cPs}$ \\
\hline
\end{tabular}

Pada hasil uji stabilitas busa diperoleh nilai yang relatif besar yaitu berkisar $80,36 \%-92,15 \%$. Persentase busa di atas $70 \%$ dikatakan baik karena masih dapat mempertahankan gelembung agar tidak pecah (Nauli dkk, 2015).

Tabel 3. Hasil uji stabilitas busa

\begin{tabular}{cc}
\hline Formula & Viskositas \\
\hline F1 & $40 \pm 0,10 \mathrm{cPs}$ \\
\hline F2 & $66 \pm 0,15 \mathrm{cPs}$ \\
\hline F3 & $83 \pm 0,20 \mathrm{cPs}$ \\
\hline
\end{tabular}

\section{PEMBAHASAN}

\subsection{Uji Organoleptik}

Berdasarkan hasil uji organoleptik tersebut dapat disimpulkan bahwa perbedaan konsentrasi $\mathrm{NaCl}$ tidak berpengaruh pada bau sediaan facial wash yakni sama-sama memiliki bau vanila. Namun penambahan variasi konsentrasi $\mathrm{NaCl}$ berpengaruh pada bentuk dan warna sediaan facial wash. Pada formula 1 diperoleh sediaan dengan konsistensi cair, pada formula 2 yaitu cair sedikit kental dan pada formula 3 yaitu cair sedikit lebih kental. Dari segi bentuk, ketiga formula facial wash menghasilkan peningkatan kekentalan seiring dengan penambahan konsentrasi $\mathrm{NaCl}$. Mengingat bahwa $\mathrm{NaCl}$ merupakan garam inorganik yang digunakan sebagai pengental dalam sebagian besar sediaan kosmetik yang mengandung detergent (Oudt, 2004), sehingga seiring dengan penambahan konsentrasi $\mathrm{NaCl}$ pada ketiga formula jelas akan menyebabkan peningkatan kekentalan.

Dari segi warna, ketiga formula menghasilkan warna berbeda. Hal ini disebabkan oleh penambahan variasi konsentrasi $\mathrm{NaCl}$, dan minyak nyamplung. Karena garam yang ditambahkan memberikan pengaruh terhadap kejernihan dari sediaan facial wash (Kurniawati dkk, 2015). Warna yang dihasilkan disebabkan oleh senyawa resin yang berwarna hijau pada minyak nyamplung (Kraftiadi, 2011), sehingga semakin bertambah konsentrasi $\mathrm{NaCl}$, sediaan facial wash yang awalnya berwarna hijau menjadi semakin berkurang warna hijaunya, ditandai dengan hasil warna yang menjadi hijau keputihan.

\subsection{Uji pH}

Derajat keasaman atau $\mathrm{pH}$ merupakan parameter kimia untuk mengetahui suatu sediaan bersifat asam atau basa. Produk kosmetik sebaiknya dibuat dengan menyesuaikan $\mathrm{pH}$ kulit, yaitu berkisar 4,56,5 (Rizky dkk, 2013). pH sabun terjadi karena bergantung pada jenis lemak yang digunakan. Sabun yang dibuat dari minyak nabati mempunyai $\mathrm{pH}$ antara 9-10 (Wijana, dkk, 2009). Pada penelitian ini digunakan minyak kelapa dan minyak zaitun sehingga diperoleh $\mathrm{pH}$ yang relatif basa, namun hal ini masih dapat ditoleransi oleh kulit. Karena sabun dapat meningkatkan $\mathrm{pH}$ kulit sementara, akan tetapi kenaikan tersebut tidak akan melebihi nilai 7 (Ismanto dkk, 2016). Berdasarkan SNI No 06-4085-1996 syarat pH sabun cair antara 8-11. Hal ini berarti $\mathrm{pH}$ facial wash dari ketiga formula memenuhi persyaratan SNI. Pada hasil uji analisis statistik $\mathrm{pH}$ yang dilakukan pada ketiga formula menunjukkan data terdistribusi normal dan homogen sehingga dapat dilanjutkan dengan uji One way ANOVA. Pada uji One way ANOVA diperoleh nilai sig $>0,05$, yang berarti variasi konsentrasi $\mathrm{NaCl}$ tidak berpengaruh nyata terhadap $\mathrm{pH}$ sediaan facial wash.

\subsection{Uji Viskositas}

Viskositas menentukan kemudahan suatu molekul bergerak karena adanya gesekan antar lapisan material. Karenanya viskositas menunjukkan tingkat ketahanan suatu cairan untuk mengalir (Lubis, 2018). Tujuan uji ini untuk mengetahui 
konsistensi sediaan facial wash, karena hal tersebut dapat mempengaruhi kemudahan sediaan untuk mengalir. Hasil uji disajikan pada tabel $\mathrm{V}$ di bawah ini.

$\mathrm{NaCl}$ merupakan garam inorganik yang digunakan sebagai pengental dalam sebagian besar sediaan kosmetik yang mengandung detergent, termasuk sabun wajah (Oudt, 2004), sehingga seiring dengan penambahan konsentrasi $\mathrm{NaCl}$ pada ketiga formula jelas akan menyebabkan peningkatan kekentalan.

Berdasarkan Tabel 2 dapat dilihat ketiga formula memiliki rata-rata nilai viskositas 40-83 cPs lebih rendah dibandingkan persyaratan SNI tentang viskositas sabun cair. Menurut SNI 064085-1996 persyaratan viskositas sabun cair berada dalam rentang 500-20000 cPs. Menurut Wijana dkk, (2009), penurunan viskositas akibat peningkatan rasio air/sabun dikarenakan viskositas dipengaruhi oleh kadar air dalam sabun tersebut. Makin sedikit kadar air dalam sabun viskositas semakin tinggi, dan sebaliknya makin banyak kadar air dalam sabun maka viskositas semakin rendah.

Hasil analisis statistik menunjukkan bahwa data viskositas yang diperoleh terdistribusi secara normal dan homogen, sehingga dilanjutkan dengan uji One Way ANOVA (lampiran 14). Pada uji One Way ANOVA diperoleh hasil sig $<0,05$ yang menandakan bahwa variasi konsentrasi $\mathrm{NaCl}$ berpengaruh nyata terhadap viskositas sediaan.

\subsection{Uji Stabilitas Busa}

Pengujian stabilitas busa dilakukan dengan tujuan untuk mengetahui pengaruh penambahan $\mathrm{NaCl}$ terhadap stabilitas busa dari ketiga formula. Pada umumnya parameter kestabilan busa ini dilakukan sesuai permintaan konsumen, karena parameter kestabilan busa belum memiliki standar persyaratan yang tetap (Kurniawati dkk, 2015). Nilai stabilitas busa tersebut menunjukkan hasil yang relatif stabil dalam waktu 5 menit. Namun, nilai stabilitas busa pada ketiga formula mengalami penurunan seiring dengan meningkatnya konsentrasi $\mathrm{NaCl}$. Hasil ini sesuai dengan penelitian (Wang, 2014), bahwa penambahan konsentrasi elektrolit menurunkan kestabilan busa. Hasil uji statistik ANOVA juga diperoleh hasil sig < 0,05 (lampiran 15). Hasil tersebut menunjukkan bahwa variasi konsentrasi $\mathrm{NaCl}$ berpengaruh signifikan terhadap stabilitas busa.

\section{Kesimpulan}

Penambahan $\mathrm{NaCl}$ dengan variasi konsentrasi berpengaruh signifikan terhadap respon viskositas dan stabilitas busa sediaan facial wash ekstrak spirulina dan minyak nyamplung. Namun tidak berpengaruh signifikan terhadap $\mathrm{pH}$ sediaan.

Berdasarkan hasil uji fisik dan kimia, karakteristik facial wash ekstrak spirulina dan minyak nyamplung yang paling baik terdapat pada formula 3 dengan konsentrasi $\mathrm{NaCl} 3 \%$, karena memenuhi syarat mutu sabun cair berdasarkan Standar Nasional Indonesia.

\section{Daftar Pustaka}

Agustini, N. W. S., 2012, Aktivitas Antioksidan dan Uji Toksisitas Hayati Pigmen Fikobiliprotein dari Ekstrak Spirulina platensis, Prosiding Seminar Biologi, 9(1).

Apriani, D., Amaliawati, N., dan Kurniati, E., 2014, Efektivitas Berbagai Konsentrasi Infusa Daun Salam (Eugenia polyantha Wight) terhadap Daya Antibakteri Staphylococcus aureus Secara In Vitro, Jurnal Teknologi Laboratorium, 3(1).

Athar, M. dan Nasir, S. M, 2005, Taxonomic Perspective of Plant Species Yielding Vegetable Oils Used in Cosmetics and Skin Care Products. African Journal of Biotechnology, 4(1): 36-44.

Australian Botanical Products, 2011, Tamanu Oil: A Unique Tropical 
DOI : https://doi.org/10.24843/JFU.2021.v10.i01.p11

Healing Oil, Abp.

Ayustaningwarno, F., 2014, Teknologi Pangan Teori Praktis dan Aplikasi, Graha Ilmu, Yogyakarta, pp. 1-2.

Badan Standarisasi Nasional, 1996, Syarat Mutu Sabun Cair: SNI 064085-1996, Jakarta: Dewan Standardisasi Nasional.

Bashandy, S.A.E., El Awdan S.A., Ebaid H. and Alhazza I.M., 2016, Antioxidant Potential of Spirulina platensis Mitigates Oxidative Stress and Reprotoxicity Induced by Sodium Arsenite in Male Rats, Oxidative Medicine and Cellular Longevity.

Boucher, C., 2000, Calophyllum oil extracted at ambient temperature has UV protecting, antiradical, antioxidant, antiaging and therapeutic properties, FR9907772A.

Dweck, A. C, and Meadows, T, 2002, Tamanu (Calophyllum inophyllum) the African, Asian, Polynesian and Pacific Panacea, International Journal of Cosmetic Science, Vol 24, Page 18.

Hasibuan, S., Sahirman., dan Yudawati, N. M. A., 2013, Karakteristik Fisokimia dan Antibakteri Hasil Purifikasi Minyak Biji Nyamplung (Calophylum inophyllum L.), Agritech, 33 (3).

Hieu, Nguyen Huu., Thuy, Tran Thi Minh, 2016, Chemical Composition Analysis and Antibacterialantiinflammatoryactivity Tests of Tamanu Seed Oil Extracted by Supercritcial Fluid Technology, Science \& technology development, Vol 19, No.K6.

Ismanto, S. D., Neswati, dan Amanda, S., 2016, Pembuatan Sabun Padat Aromaterapi dari Minyak Kelapa Murni (Virgin Coconut Oil) dengan Penambahan Minyak Gubal Gaharu (Aquilaria malaccensis), Jurnal Teknologi Pertanian Andalas, 20(2).

Kratiadi, Suhartono, 2011, Analisis Energi pada Proses Pembuatan Minyak Nyamplung, skripsi, Teknologi
Pertanian IPB.

Kurniawati, Y., Wardoyo, S, E., dan Arizal, R., 2015, Optimasi Penggunaan Garam Elektrolit Sebagai Pengental Sampo Bening Cair, Jurnal Sains Natural Universitas Nusa Bangsa, 5(1), 30-41.

Kurniawati, Y., Wardoyo, S, E., dan Arizal, R., 2015, Optimasi Penggunaan Garam Elektrolit Sebagai Pengental Sampo Bening Cair, Jurnal Sains Natural Universitas Nusa Bangsa, 5(1), 30-41.

Liu Y., Lizhi X., Cheng N., Lin L., dan Zhang C., 2000, Inhibitory effect of phycocyanin from Spirulina platensis on the growth of human leukemia K562 cell, Applied Phycology, 12:125-130.

Lubis, N. A., 2018, Pengaruh Kekentalan Cairan terhadap Waktu Jatuh Benda Menggunakan Falling Ball Method, Jurnal Ilmu Fisika dan Teknologi, 2(2), 26-32.

Musfiroh, I., Indriyati, W., Muchtaridi dan Setiya, Y., 2007, Analisis proksimat dan penetapan kadar $\beta$-karoten dalam selai lembaran terung belanda cyphomandra betacea sendtn dengan metode spektrofotometri sinar tampak, Jurnal, Fakultas Farmasi Universitas Padjajaran, Bandung.

Nauli, A., P., Darmanto, Y., S., dan Susanto, E., 2015, Karakteristik Sabun Cair Dengan Penambahan Kolagen Ikan Air Laut Yang Berbeda, J. Peng. \& Biotek, 4(4).

Nurhadi, S.C., 2012, Pembuatan Sabun Mandi Gel Alami dengan Bahan Aktif Mikroalga Chlorrela pyrenoidosa Beyerinck dan Minyak Atsiri Lavandula lativolia Chaix, Skripsi, Program Studi Teknik Industri Fakultas Sains dan Teknologi, Universitas Ma Chung, Malang.

Oudt, Caroline, 2004, Thickening of Foaming Cosmetic Formulations, CD Proceeding 6th World Surfactant Congress, Germany, 1-9. 
DOI : https://doi.org/10.24843/JFU.2021.v10.i01.p11

Rejeki, S., dan Sri, S. W., 2015, Formulasi Gel Tabir Surya Minyak Nyamplung (Tamanu Oil) Dan Uji Nilai Spf Secara In Vitro, Skripsi, Program Studi Farmasi, Poltekkes Bhakti Mulia.

Rizky, A.W., Latifa, dan Winarni, P., 2013, Formulasi Krim Ekstrak Lidah Buaya (Aloe vera) sebagai Alternatif Penyembuhan Luka Bakar, Indonesian Journal of Chemical Science.

Sari, D. K., Marliyati, S. A., Kustiyah, L., Khomsan, A., dan Gantohe, T. M., 2014, Uji Organoleptik Formulasi Biskuit Fungsional Berbasis Tepung Ikan Gabus (Ophiocephalus striatus), Agritech, 34(2), 120-125.

Sikder, M. A. A., Saha, R., Rokibuzzaman, M., Sharmin, T., Rashid, R. B., Uddin, M. Z., dan Rashid, M. A., 2013, Preliminary Biological Investigations of Lophopetalum fimbriatum and Calophyllum inophyllum, Bangladesh Pharmaceutical Journal, 16(2):205209.

Sinatrya, M., 2009, Sifat Organoleptik Sabun Transparan Dengan Penambahan Madu, Skripsi, Fakultas Peternakan, Institut Pertanian Bogor: Bogor.

Wang, C., dan Huazhou, L., 2014, Foam Stability of Solvent/Surfactant/HeavyOil System Under Reservoir Conditions, 5-9.

Wijana, S., Sumarjo \& Harnawi, T., 2009, Studi pembuatan sabun mandi cair dari daur ulang minyak goreng bekas (Kajian pengaruh lama pengadukan dan rasio air:sabun terhadap kualitas), Jurnal Teknologi Pertanian, 10(1): 5461.

Wijana, S., Sumarjo \& Harnawi, T., 2009, Studi pembuatan sabun mandi cair dari daur ulang minyak goreng bekas (Kajian pengaruh lama pengadukan dan rasio air:sabun terhadap kualitas), Jurnal Teknologi Pertanian, 10(1): 5461.

Yuniarti, R. A., 2004, Studi Kualitas Busa Sabun Mandi Cair Ditinjau dari Jenis
Bahan Aktif dan Konsentrasi Terhadap Berbagai Tingkat Air Sadah, Skripsi, Fakultas Matematika dan Ilmu Pengetahuan Alam. Universitas Nusa Bangsa. Bogor. 